\title{
Volatiles Production and Lipoxygenase Gene Expression in Kiwifruit Peel and Flesh During Fruit Ripening
}

\author{
Bo Zhang, Xue-Ren Yin, Ji-Yuan Shen, and Kun-Song Chen ${ }^{1}$ \\ Laboratory of Fruit Molecular Physiology and Biotechnology/The State Agriculture Ministry \\ Laboratory of Horticultural Plant Growth, Development and Quality Improvement, Huajiachi \\ Campus, Zhejiang University, Hangzhou 310029, P.R. China
}

Ian B. Ferguson

The New Zealand Institute for Plant and Food Research, Private Bag 92169, Auckland 1025, New Zealand

\begin{abstract}
AdDitional INDEX words. ethylene, kiwifruit, lipoxygenase, volatiles
ABstract. The relationship between lipoxygenase (LOX) pathway-derived volatiles and LOX gene expression was evaluated in kiwifruit [Actinidia deliciosa (A. Chev.) C.F. Liang et A.R. Ferguson var. deliciosa cv. Bruno] during postharvest ripening at $20^{\circ} \mathrm{C}$. The $\mathrm{C} 6$ aldehydes $n$-hexanal and $(E)$-2-hexenal were abundant in peel compared with flesh tissue and declined as kiwifruit ripened. Esters such as ethyl butanoate and methyl butanoate were lower in the peel than flesh and accumulated when the fruit underwent a climacteric rise in ethylene production. Total LOX activity was higher in the peel than in the flesh and increased as kiwifruit ripened. Expression of AdLox2, AdLox3, AdLox4 and AdLox6 was high in the peel, whereas AdLox1 and AdLox5 showed similar levels in the peel and flesh at the ethylene climacteric. AdLox 1 and AdLox 5 transcript levels increased and AdLox2, AdLox3, AdLox4 and AdLox6 levels decreased during postharvest fruit ripening. Principal component analysis showed that $n$-hexanal and $(E)$-2hexenal were grouped with LOX genes that were downregulated as kiwifruit ripened. The possible roles of LOX genes in relation to kiwifruit volatile formation during fruit ripening are discussed.
\end{abstract}

Change in fruit volatile production is one of the main processes occurring during fruit ripening and senescence. Fatty acid-derived straight-chain aldehydes produced through the lipoxygenase (LOX) pathway are widely found in many fruit (Baldwin, 2002), and LOX-mediated peroxidation converts linoleic acid and linolenic acid to $n$-hexanal and $(E)$-2-hexenal, respectively (Hatanaka, 1993). The positive relationship between LOX activity and C6 aldehydes has been observed in olive (Olea europea L.) (Ridolfi et al., 2002), apple (Malus $\times$ domestica Borkh.) (Lara et al., 2006), pear (Pyrus communis L.) (Lara et al., 2003), strawberry (Fragaria ×ananassa Duch.) (Leone et al., 2006), and kiwifruit (Zhang et al., 2009). LOX genes that are specifically involved in tomato fruit volatile generation have been identified, and downregulation of TomLoxC caused a 98.5\% reduction in $\mathrm{C} 6$ aldehydes as tomato (Solanum lycopersicum L.) fruit ripened (Chen et al., 2004). Conversely, silencing of fruit ripening-related TomLoxA and TomLoxB had no effect on volatile formation (Griffiths et al., 1999).

Ethylene also plays a regulatory role in volatile generation as fruit ripen (Flores et al., 2002). In 'Royal Gala' apple, Schaffer et al. (2007) generated a transgenic line using antisense ACC oxidase (ACO) that produced no detectable ethylene and resulted in fruit with low aroma levels. External ethylene treatment could

Received for publication 17 Apr. 2009. Accepted for publication 7 July 2009. This work was supported by the National Natural Science Foundation of China (30771495), the Post-Doctoral Funding of China (20070421208), the 111 project (B06014), and Zhejiang University K. P. Chao's Hi-Tech Foundation for Scholars and Scientists.

We thank Dr. Li-Min Zhu and Ming-Hui Ma (Aplha MOS) and Dr. Nihal De Silva (Plant and Food Research) for their statistical advice.

${ }^{1}$ Corresponding author. E-mail: akun@zju.edu.cn. restore the fruit's ability to undergo normal ripening, including aroma volatile formation. LOX genes associated with the apple fruit aroma biosynthesis pathway were also under ethylene regulation (Schaffer et al., 2007). Ethylene treatment has also been shown to induce LOX activity and promote volatile formation in ripening apple fruit, whereas treatment with the ethylene action inhibitor 1-methylcyclopropene maintained low levels of enzyme activity and volatile compounds compared with untreated controls (Li et al., 2006).

Aroma volatiles have been shown to have different distributions in fruit parts. Peach [Prunus persica (L.) Batsch] skin has a considerably higher concentration of $n$-hexanal and $(E)$ 2-hexenal and a several fold higher concentration of the corresponding alcohols than pulp tissue (Aubert and Milhet, 2007). In mango fruit (Mangifera indica L.), the levels of volatiles in the skin were also significantly higher than those observed in the pulp (Lalel et al., 2003). Results from ACO antisense 'Greensleeves' apple fruit suggested that volatiles from the peel and the flesh were both regulated by ethylene (Defilippi et al., 2005).

Kiwifruit volatiles have been well studied with 80 to 90 compounds identified (Friel et al., 2007; Matich et al., 2003; Wan et al., 1999; Young and Paterson, 1985). In general, aldehydes are more abundant in unripe fruit and esters in ripe fruit with $n$-hexanal, $(E)$-2-hexenal and ethyl butanoate identified as specific kiwifruit volatiles (Gilbert et al., 1996; Young and Paterson, 1985). In our previous study with kiwifruit, six LOX genes were characterized with AdLox 1, AdLox3, AdLox4 and AdLox6 grouped into the 13-LOX family and AdLox2 and AdLox5 clustered into the 9-LOX family (Zhang et al., 2006). These LOX genes showed different expression patterns during kiwifruit ripening at $20{ }^{\circ} \mathrm{C}$ and in response to fatty acid 
treatments, and roles for AdLox 1 and AdLox5 in fruit ripening and a relationship of AdLox4 and AdLox6 with flesh tissue volatile production have been suggested (Zhang et al., 2009).

In most of the previous reports, volatiles were extracted from kiwifruit flesh tissue. The distribution of volatiles between the peel and flesh tissues during fruit ripening remains unclear. The suggested involvement of LOX in kiwifruit volatile formation prompted us to evaluate further the relationship between LOX gene expression and volatile formation in the flesh as well as in the peel at different ripening stages. The present study may provide a clue to explain the different distribution of volatiles in fruit parts and to understand the role of LOX genes in kiwifruit volatile generation.

\section{Materials and Methods}

Plant material and SAmpling. 'Bruno' kiwifruit were harvested at a total soluble solids concentration of $6.8 \%$ from an orchard at Wuyi, Zhejiang, China. Medium-sized (80-120 g) fruit, free from visible defects or decay, were selected. During fruit ripening, care was taken also to exclude fruit with any symptoms of decay. To follow fruit ripening, fruit were held at $20{ }^{\circ} \mathrm{C}$ and $92 \%$ to $98 \%$ relative humidity. In the 2007 season, two fruit ripening stages were selected for study of volatile production from peel and flesh tissue. The first stage consisted of fruit on the day of harvest [ $0 \mathrm{~h}$ (ethylene production was below detectable limits)], and the second-stage fruit were selected when the ethylene production climacteric began [96 $\mathrm{h}$ after harvest $\left(9.75 \mathrm{~nL} \cdot \mathrm{g}^{-1} \cdot \mathrm{h}^{-1}\right.$ ethylene $\left.)\right]$. In the 2006 season, the flesh of kiwifruit with different rates of ethylene production were sampled during postharvest ripening. At sampling time, slices of flesh and peel tissues $(\approx 1 \mathrm{~mm}$ thick) were carefully separated using a sharp blade at the equatorial part of the fruit as described for firmness determination and frozen in liquid nitrogen and kept at $-80{ }^{\circ} \mathrm{C}$ until analyzed. For biochemical and molecular analysis, three replicates of five fruit each were used.

Fruit RIPENING. Rates of ethylene production and fruit firmness were measured as described in Zhang et al. (2006). Six 2-L flasks, each containing three fruit, were used to measure ethylene production. The flasks were capped at $20^{\circ} \mathrm{C}$ for $1 \mathrm{~h}$. One milliliter of headspace gas was injected into a gas chromatograph (SP6800; Lunan Chemical Engineering Instrument, Shandong, China) fitted with a GDX-502 column (Lunan Chemical Engineering Instrument). The $\mathrm{N}_{2}$ carrier gas was used at a flow pressure $0.18 \mathrm{mPa}$; the air and $\mathrm{H}_{2}$ pressure used in the flame ionization detector (FID) system were controlled at 0.08 and $0.05 \mathrm{mPa}$, respectively. Temperatures for the injector, detector, and oven were 110,140 , and $90^{\circ} \mathrm{C}$, respectively. Fruit firmness was measured at the equator of the fruit with a handheld penetrometer (FT-327; Effegi, Milan, Italy) with a 7.9-mmdiameter head after the removal of a 1-mm-thick slice of peel.

Volatile ANALYsis. For fruit volatiles analysis, $5 \mathrm{~g}$ of frozen fruit tissue was ground in liquid nitrogen and transferred to a $15-\mathrm{mL}$ vial containing $5 \mathrm{~mL}$ saturated sodium chloride solution. The tissues were homogenized with an Ultra Turrax (T-25 basic; IKA, Stauffen, Germany) for $1.0 \mathrm{~min}$. Before sealing the vials, $30 \mu \mathrm{L}$ of 2 -octanol $\left(8.69 \mathrm{mg} \cdot \mathrm{mL}^{-1}\right)$ was added as an internal standard and stirred for $10 \mathrm{~s}$ with a Vortex-Genie 2 (Scientific Industries, Bohemia, NY). Volatile formation was measured using an end point assay. For manual solid-phase microextraction analysis, samples were equilibrated at $40{ }^{\circ} \mathrm{C}$ for $30 \mathrm{~min}$ and then exposed to a $65-\mu \mathrm{m}$ CAR-DVB fiber
(Supelco, Bellefonte, PA) for $10 \mathrm{~min}$. A gas chromatograph (6890N; Agilent Technologies, Santa Clara, CA) with an FID detector and equipped with a DB-WAX column $(0.32 \mathrm{~mm}$, $30 \mathrm{~m}, 0.25 \mu \mathrm{m}$; Agilent Technologies) was used for volatile analysis. Chromatograph conditions were as follows: injector $220{ }^{\circ} \mathrm{C}$, initial oven temperature $34^{\circ} \mathrm{C}$ held for $2 \mathrm{~min}$, increased by $2^{\circ} \mathrm{C} / \mathrm{min}$ to $60^{\circ} \mathrm{C}$, then increased by $4^{\circ} \mathrm{C} / \mathrm{min}$ to $180^{\circ} \mathrm{C}$, and held for $2 \mathrm{~min}$. Nitrogen was used as a carrier gas with a mean linear velocity of $1.1 \mathrm{~mL} \cdot \mathrm{min}^{-1}$. Volatiles were identified by comparison of retention times with those of authentic standards (Sigma-Aldrich, St. Louis, MO). Quantitative determination of compounds was carried out using the peak of the internal standard as a reference value and calculated based on the standard curve of authentic compounds.

LiPOXYGENASE ACTIVITY ASSAY. Total LOX enzyme extraction was carried out according to Zhang et al. (2009). Briefly, $1 \mathrm{~g}$ of frozen tissue was extracted in $5 \mathrm{~mL}$ of $50 \mathrm{~mm}$ phosphate buffer (pH 7.0) containing 0.1\% (v/v) Triton X-100 and $0.2 \mathrm{~g}$ PVPP (Sigma-Aldrich). The homogenates were centrifuged for $20 \mathrm{~min}$ at $15,000 \mathrm{~g}_{\mathrm{n}}$, and the supernatant was used as a crude extract. A $3-\mathrm{mL}$ reaction mixture consisted of $2.75 \mathrm{~mL}$ of $100 \mathrm{~mm}$ acetate buffer ( $\mathrm{pH} 5.4$ ), $50 \mu \mathrm{L}$ of $0.17 \mathrm{~mm}$ linoleic acid, and $200 \mu \mathrm{L}$ of crude extract. The total enzyme activity was expressed as micromoles of hydroperoxide per minute per milligram of protein using a molar extinction coefficient of $25,000 \mathrm{M}^{-1} \cdot \mathrm{cm}^{-1}$. Protein measurements were performed using a Protein Assay kit (Bio-Rad, Hercules, CA) according to Bradford (1976) using bovine serum albumin as a standard.

REAL-TIME QUANTITATIVE REVERSE TRANSCRIPTASEPOLYMERASE CHAIN REACTION ANALYSIS. Total RNA was extracted from frozen fruit tissue according to the method described by Zhang et al. (2006). First-strand cDNA was synthesized using $1.0 \mu \mathrm{g}$ of DNase I (LT-02241; Fermentas, Vilnius, Lithuania) treated total RNA, $0.5 \mu \mathrm{g}$ of oligo d(T) $)_{18}$, and $200 \mathrm{U}$ of RevertAid ${ }^{\mathrm{TM}} \mathrm{M}-\mathrm{MuLV}$ reverse transcriptase (Fermentas) to a total volume of $20 \mu \mathrm{L}$. Polymerase chain reactions (PCRs) were performed in a total volume of $20 \mu \mathrm{L}$, $250 \mu \mathrm{M}$ for each primer, $10 \mu \mathrm{L}$ of $2 \times$ SYBR Green PCR Master Mix (Bio-Rad), and 2.0 $\mu \mathrm{L}$ of the first-strand cDNA in iCycler iQ real-time PCR instrument (Bio-Rad). The real-time quantitative reverse transcriptase-PCR (qPCR) program included a preliminary step of $5 \mathrm{~min}$ at $94{ }^{\circ} \mathrm{C}$ followed by 45 cycles of $94{ }^{\circ} \mathrm{C} \times 10 \mathrm{~s}$ and $60{ }^{\circ} \mathrm{C} \times 30 \mathrm{~s}$. No-template controls for each primer pair were included in each run. Kiwifruit actin was used as an internal control to normalize small differences in template amounts. LOX gene family and actin primers used for qPCR analysis were the same as those described in Zhang et al. (2006). At least three different RNA isolations and cDNA syntheses were used as replicates for the qPCR. Expression levels produced by qPCR were expressed as a ratio relative to the fruit flesh tissue at the harvest time point, which was set to 1 .

Statistical ANALYsis. SES and figures were made by Origin (Microcal Software, Northampton, MA), and differences indicated in the figures were based on Tukey's test at the 5\% level (DPS Version 2.00; Zhejiang University, Hangzhou, China). To provide a general overview of the relationship between volatile production and LOX gene expression, a principal component analysis (PCA) was developed using AlphaSoft (Version 11.0; Alpha MOS, Toulouse, France). The PCA presentation was chosen to show patterns, not functional relationships. Samples were characterized by volatile emissions and LOX gene expression. Data were centered and weighted by using the data 
reduction algorithm to avoid dependence on measured units and to reduce the weight of large peaks so that the minor peaks have the same impact. This methodology ensures that the weighting on variables in the PCA is not unit-dependent; otherwise, larger valued units that vary more will be dominant in the PCA.

\section{Results and Discussion}

VOLATILES IN PEEL AND FLESH IN RIPENING KIwIFRUIT. Previous studies have shown that kiwifruit volatiles underwent substantial changes (Young and Paterson, 1985; Zhang et al., 2009) when the fruit climacteric had begun $(96 \mathrm{~h}$ after harvest, $9.75 \pm 3.74$ $\left.\mathrm{nL} \cdot \mathrm{g}^{-1} \cdot \mathrm{h}^{-1}\right)$. By this time, fruit held at $20^{\circ} \mathrm{C}$ softened from $71.54 \mathrm{~N}$ (at harvest) to $\approx 13.5 \mathrm{~N}$ after $96 \mathrm{~h}$ ripening. Levels of C6 aldehydes and alcohols were higher in kiwifruit at harvest, whereas esters accumulated when the fruit began to ripen (Fig. 1). The peel had considerably higher concentrations of $n$ hexanal and (E)-2-hexenal (Fig. 1A-B) and several fold higher levels of $n$-hexanol and (E)-2-hexenol (Fig. 1C-D) than the flesh at harvest or at $96 \mathrm{~h}$ after harvest. Higher concentrations of $\mathrm{C} 6$ volatile compounds in the peel than in the flesh have also been reported in apple (Defilippi et al., 2005), mango (Lalel et al., 2003), and peach fruit (Aubert and Milhet, 2007). In contrast to C6 aldehydes and alcohols, esters mainly accumulated in the flesh tissue (Fig. 1E-F). Methyl butanoate was only detected in the flesh after the ethylene climacteric rise had begun. It has been reported that C6 aldehydes and alcohols endow kiwifruit with intense grassy notes, whereas esters give fruity flavor notes as the fruit ripen (Gilbert et al., 1996). The present data from the peel would suggest different regulation of volatile compounds in the peel and flesh.

TOTAL LIPOXYGENASE ENZYME ACTIVITY IN THE PEEL AND THE FLESH. Fig. 2 shows that total LOX enzyme activity in the peel was considerably higher than in the flesh tissue. This is similar to what occurs in other fruit, in which apple fruit had higher LOX activity in the peel (Defilippi et al., 2005), and tomato LOX activity was mainly localized between the peel and the flesh (Hatanaka et al., 1992). The enzyme activity in the peel and flesh was consistent with levels of the LOX pathway products $n$ hexanal and $(E)$-2-hexenal (Fig. 1A-B). Long-term controlled atmosphere storage has been shown to cause a decrease in LOX activity, and this was suggested as a possible reason for the decrease in volatiles in pear (Lara et al., 2003) and apple fruit (Lara et al., 2006). Treatment of kiwifruit with the LOX action inhibitor nordihydroguariaretic acid resulted in a significant decrease in LOX activity and C6 aldehydes (Zhang et al., 2009). The present data show that total LOX activity increased slightly as the fruit ripened, although these increases were not significant at the $5 \%$ level (Fig. 2). Increases with ripening have been previously reported in kiwifruit (Zhang et al., 2006), apple (Defilippi et al., 2005), and watermelon (Citrullus lanatus Matsum. and Nakai) (Karakurt and Huber, 2004). However, there seems to be an inverse relationship between total LOX activity and the respective aldehydes in the flesh during fruit

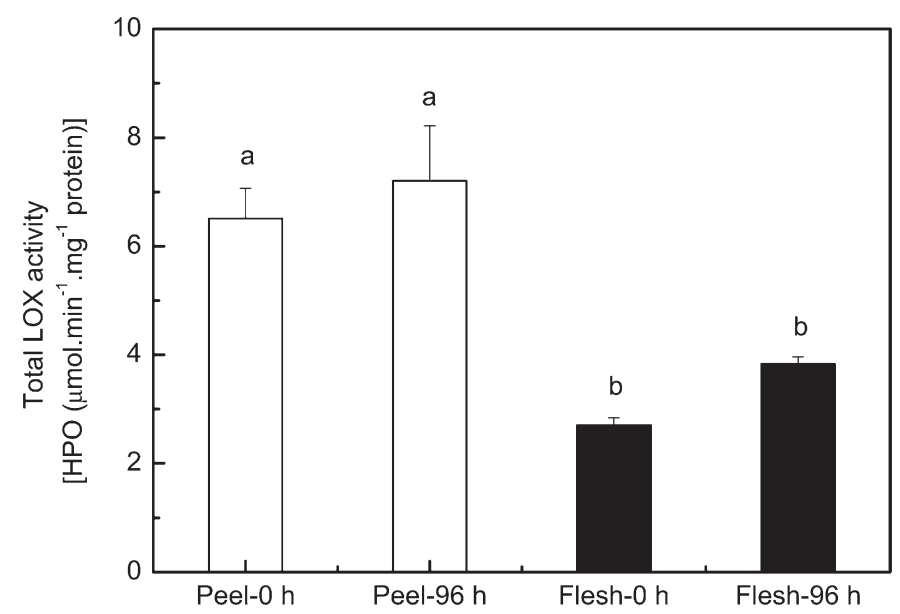

Fig. 2. Total lipoxygenase (LOX) enzyme activity [hydroperoxide (HPO)] in kiwifruit peel and flesh tissue during fruit ripening at $20^{\circ} \mathrm{C}$ in the 2007 season. Data are means \pm SE of three replicates. Values with different letters for the LOX activity are different at $P<0.05$.

ripening. This may be explained by the diverse functions of products from the LOX pathway in fruit ripening, including C6 volatiles biosynthesis and oxidative stress formation (Porta and Rocha-Sosa, 2002; Rogiers et al., 1998). In addition, previous studies showed that LOX family members have distinct functions in plants (Chen et al., 2004; León et al., 2002; Porta and RochaSosa, 2002). Analysis of LOX family expression may provide some information on the relationship of LOX and volatiles during kiwifruit ripening.

EXPRESSION OF THE LIPOXYGENASE FAMILY IN THE PEEL AND FLESH DURING KIWIFRUIT RIPENING. The six LOX genes had different distributions in the peel and the flesh tissues and 


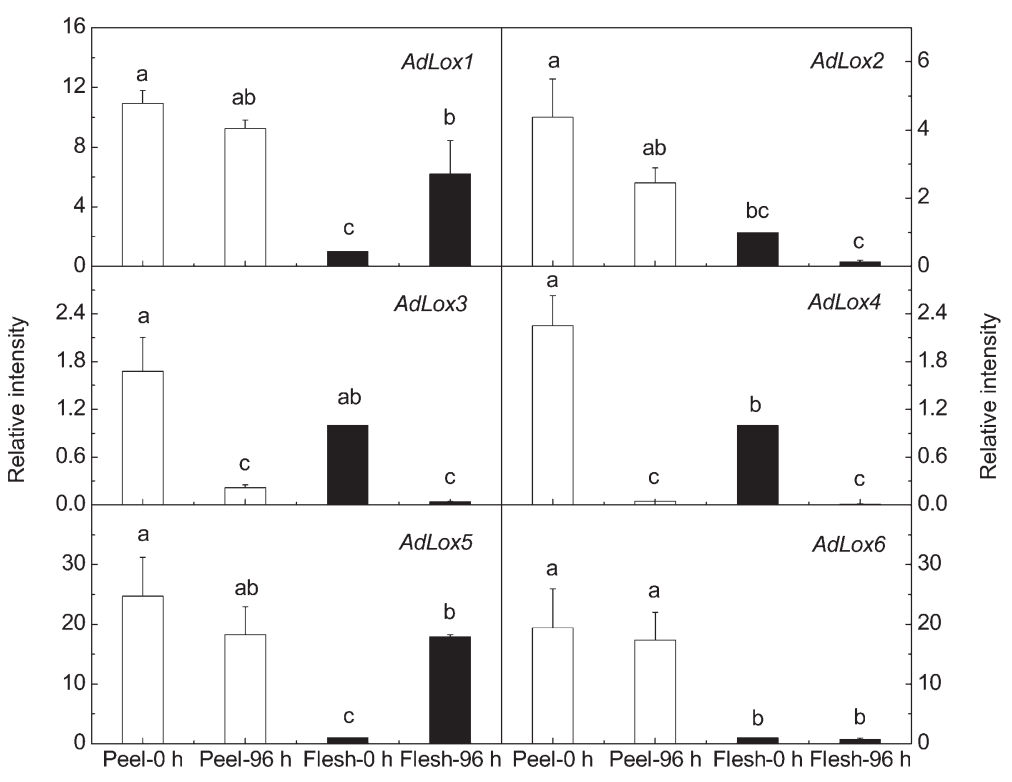

Fig. 3. Expression of lipoxygenase (LOX) genes in ripening kiwifruit using real-time quantitative polymerase chain reaction in the 2007 season. Error bars indicate SE from three replicates. Expression levels of each gene are expressed as a ratio relative to flesh tissue at the harvest time $(0 \mathrm{~h})$, which was set at 1 . Values with different letters for LOX gene expression are different at $P<0.05$.

would expect maintenance of transcript levels. The lower transcript levels in the flesh are consistent with the data in Fig. 1 showing several fold lower levels of $n$-hexanal and (E)-2-hexenal in the flesh than in the peel tissue at harvest. A similar distribution of LOX genes and C6 aldehydes in the peel and flesh was also found as kiwifruit ripened (96 $\mathrm{h}$ after harvest).

As shown in Fig. 4, principal components 1 (PC1) and 2 (PC2) accounted for $95 \%$ of the total variability when volatiles and gene expression were used to characterize the peel and the flesh at harvest and after $96 \mathrm{~h}$. In Cluster A, ripening-induced AdLoxl and AdLox5 were grouped with accumulated esters such as ethyl butanoate and methyl butanoate. The other four downregulated LOX genes and C6 aldehydes were distributed in Cluster C (Fig. 4). In tomato fruit, $n$ hexanal and $(E)$-2-hexenal were reduced by 98.5\% when TomLoxC was downregulated (Chen et al., 2004). Morever, production of C6 aldehydes was significantly inhibited in antisense StLoxH1 potato plants (Solanum tuberosum L.) (León et al., 2002). Kiwifruit

different responses between $0 \mathrm{~h}$ and $96 \mathrm{~h}$ after harvest (Fig. 3). At harvest, all genes were expressed more strongly in the peel than in the flesh. Expression of two LOX genes (AdLox3 and AdLox4) decreased during ripening, whereas any decrease with the other four genes was not significant at the 5\% level (Fig. 3). This reduction was consistent with that of $n$-hexanal and $(E)$ 2-hexenal (Fig. 1). These aldehydes give the specific kiwifruit aroma and tend to decline as kiwifruit ripen (Young and Paterson, 1985). Transcript accumulation in the flesh occurred with AdLox 1 and AdLox 5, whereas expression of the other four genes either declined or underwent no change. Because total LOX activity was maintained during ripening (Fig. 2), we
AdLox4 and AdLox6 possess putative chloroplast transit peptides and show high sequence homology with tomato TomLoxC and StLoxH1 (Zhang et al., 2006).

VOLATILE COMPOUNDS PRODUCTION AND LIPOXYGENASE GENE EXPRESSION IN RIPENING KIWIFRUIT. These results showed that volatile generation and LOX gene expression were sensitive to ripening stage and may have an association with ethylene production. To clarify the relationship among LOX, volatiles, and ethylene, the flesh of kiwifruit with different rates of ethylene production was sampled during postharvest ripening in the 2006 season. The climacteric rise of ethylene production was initiated at $\approx 180 \mathrm{~h}$, peaking at $\approx 228 \mathrm{~h}$, followed by a

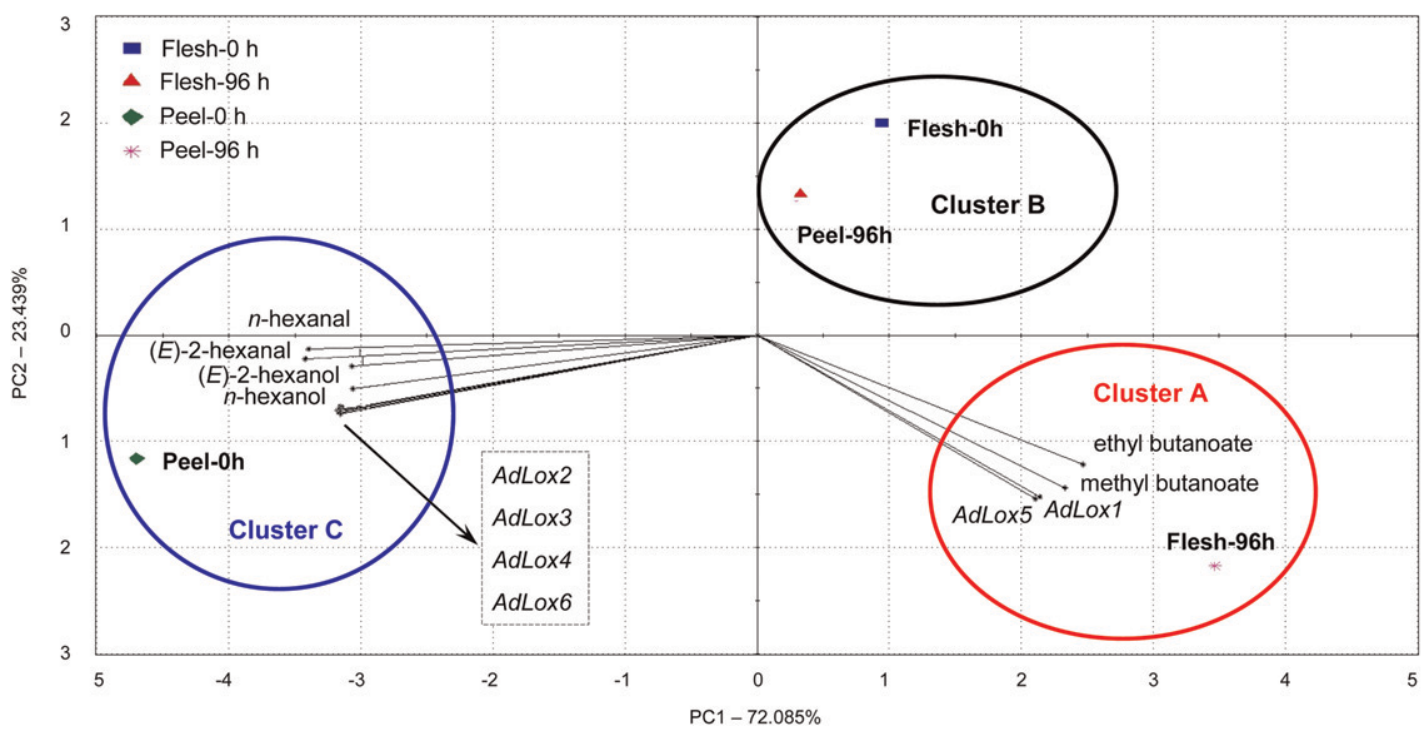

Fig. 4. Plots of loading vectors of variables and the sample mean scores for the first two principal components of principal component analysis (PCA) for kiwifruit volatiles and lipoxygenase (LOX) gene expression in both peel and flesh tissue at harvest and after $96 \mathrm{~h}$ in the 2007 season. Principal component 1 (PC1) and 2 (PC2) accounted for $72.09 \%$ and $23.44 \%$ of the variation, respectively. 
Table 1. Ethylene production, volatile formation, and percentage changes in lipoxygenase (LOX) gene expression of kiwifruit during postharvest ripening in the 2006 season. $^{\mathrm{z}}$

\begin{tabular}{|c|c|c|c|c|c|}
\hline & \multicolumn{5}{|c|}{ Time after harvest (h) } \\
\hline & 0 & 84 & 180 & 228 & 276 \\
\hline & \multicolumn{5}{|c|}{$\left[\right.$ mean $\left.\pm S E\left(n L \cdot g^{-1} \cdot h^{-1}\right)\right]$} \\
\hline Ethylene & $\mathrm{nd}^{\mathrm{y}}$ & $0.37 \pm 0.15$ & $6.82 \pm 3.74$ & $77.28 \pm 14.7$ & $36.82 \pm 14.82$ \\
\hline & \multicolumn{5}{|c|}{$\left[m e a n \pm S E\left(\mu g \cdot g^{-1} F W\right)\right]$} \\
\hline$n$-hexanal & $6.07 \pm 0.55$ & $5.12 \pm 0.67$ & $5.23 \pm 0.89$ & $2.38 \pm 0.24$ & $1.95 \pm 0.09$ \\
\hline (E)-2-hexenal & $36.24 \pm 3.02$ & $29.63 \pm 2.58$ & $27.03 \pm 3.18$ & $6.17 \pm 0.50$ & $2.99 \pm 0.55$ \\
\hline ethyl butanoate & $1.43 \pm 0.19$ & $2.39 \pm 0.13$ & $3.29 \pm 0.29$ & $31.50 \pm 5.76$ & $61.67 \pm 9.40$ \\
\hline \multirow[t]{2}{*}{ methyl butanoate } & nd & $1.87 \pm 0.35$ & $2.91 \pm 0.62$ & $31.60 \pm 5.94$ & $52.77 \pm 9.40$ \\
\hline & \multicolumn{5}{|c|}{$(\% \text { change in gene expression })^{x}$} \\
\hline AdLox 1 & 1.00 & +22.04 & +15.20 & +35.58 & +42.99 \\
\hline AdLox 2 & 1.00 & -2.40 & -10.04 & -10.32 & -15.20 \\
\hline
\end{tabular}

${ }^{\mathrm{z}}$ Kiwifruit were allowed to ripen at $20{ }^{\circ} \mathrm{C}$, and the harvest time point was set as $0 \mathrm{~h}$. All data are means of three replicates.

${ }^{y}$ Not detected in samples.

"Expression levels of LOX genes are expressed as fold changes relative to $0 \mathrm{~h}$, which was set at 1; "+” represents increasing fold, whereas " -" indicates decreasing fold.

$\mathrm{FW}=$ fresh weight.

decline (Table 1). Kiwifruit softened from $67.54 \mathrm{~N}$ at harvest to $\approx 5.0 \mathrm{~N}$ after $228 \mathrm{~h}$ ripening at $20^{\circ} \mathrm{C}$.

The volatile profile was dominated by $\mathrm{C} 6$ aldehydes at harvest and by esters after $276 \mathrm{~h}$ storage (Table 1). During ripening, green aroma volatiles $n$-hexanal and $(E)$-2-hexenal decreased in concentration. However, esters such as methyl butanoate and ethyl butanoate, which endow kiwifruit with sweet and fruity flavor notes, showed a strong increase after the ethylene climacteric was initiated (Table 1). Expression of AdLox2, AdLox3, AdLox4 and AdLox6 declined with kiwifruit softening. AdLox 1 and AdLox 5 transcripts were strongly induced during the climacteric rise in ethylene production. Changes in volatile compounds and LOX gene expression were similar to those in ripening kiwifruit, as we reported previously (Zhang et al., 2006, 2009)

When volatile compounds and LOX gene expression were again used for PCA analysis, kiwifruit ripening stages were separated into three groups (Fig. 5). In this case, the first two principal components accounted for more than $90 \%$ of the variation. Samples at harvest $(0 \mathrm{~h})$, without detectable ethylene production, were characterized by $n$-hexanal, $(E)$-2-hexenal, (E)-2-hexenol, (Z)-2-hexenol, AdLox2, AdLox3, AdLox4 and

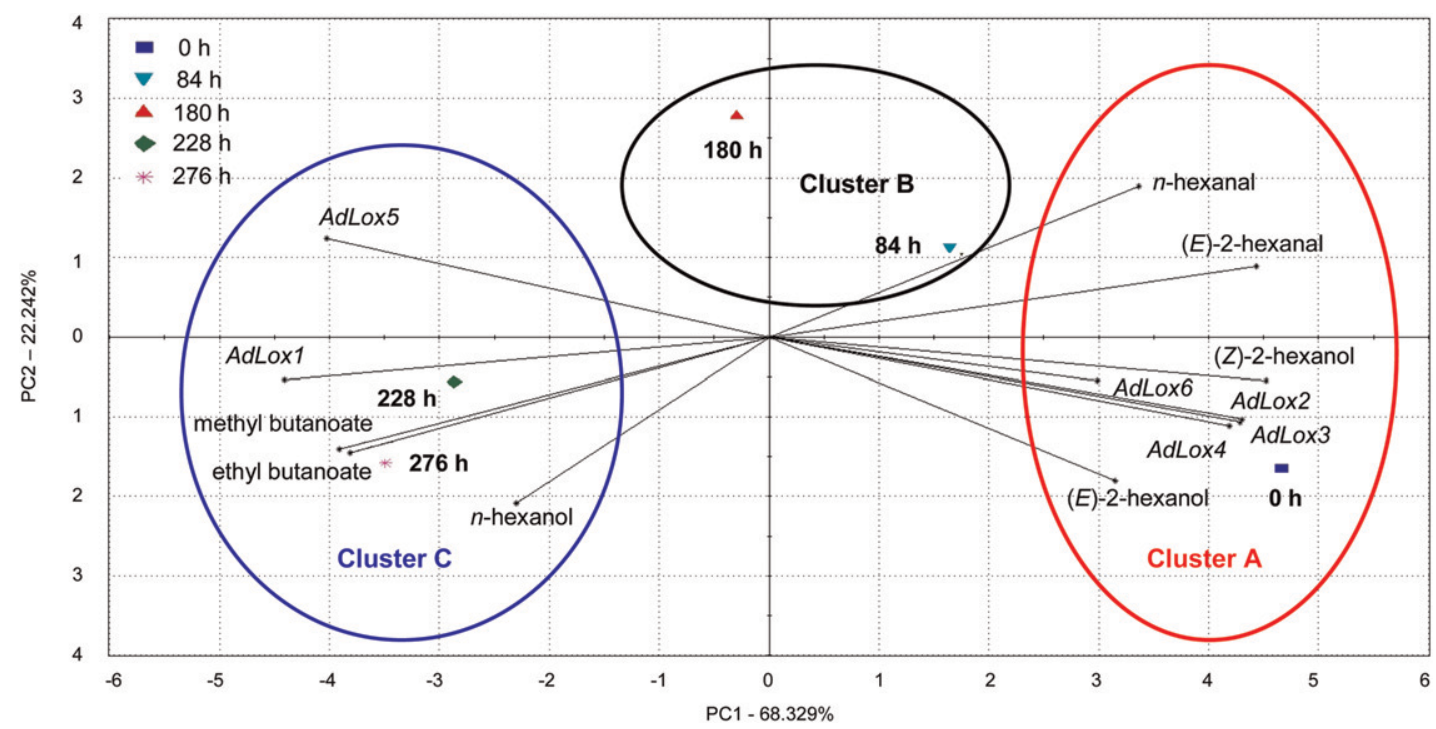

Fig. 5. Plots of loading vectors of variables and the sample mean scores for the first two principal components of principal component analysis (PCA) for kiwifruit flesh volatiles and lipoxygenase gene expression with ripening at $20{ }^{\circ} \mathrm{C}$ (2006 season). Principal component 1 (PC1) and 2 (PC2) accounted for $68.33 \%$ and $22.24 \%$ of the variation, respectively. 
AdLox6 and were separated from other samples during kiwifruit ripening (Fig. 5), indicating that these volatiles and genes were mainly predominant in unripe fruit. Cluster B consisted of samples at 84 and $180 \mathrm{~h}$ after harvest (Fig. 5). Cluster C consisted of fruit at 228 and $276 \mathrm{~h}$ after harvest characterized by volatiles such as $n$-hexanol, methyl butanoate, and ethyl butanoate and the LOX genes AdLoxl and AdLox 5 (Fig. 5). The PCA analysis showed that downregulated LOX genes and C6 aldehydes were grouped, and upregulated LOX genes were clustered with accumulated esters associated with kiwifruit ripening and senescence. However, the relationship of other enzymatic steps such as hydroperoxide lyase, alcohol dehydrogenase, and alcohol acyltransferase with volatile generation as kiwifruit ripened needs further study.

The present study showed that C6 aldehydes $n$-hexanal and (E)-2-hexenal derived from the LOX pathway were higher in the peel than the flesh and tended to decrease as kiwifruit ripened. Similar patterns were found for gene expression of AdLox2, AdLox3, AdLox4 and AdLox6. Fruity esters such as methyl butanoate and ethyl butanoate accumulated mainly in the flesh when fruit developed climacteric-type ethylene production and accompanied an increase in expression of AdLoxI and AdLox 5 as the fruit ripened. These data provide further information on the individual expression patterns of specific LOX genes in relation to aroma volatile production, suggesting that individual genes must be studied in determining mechanisms for volatile production in fruit.

\section{Literature Cited}

Aubert, C. and C. Milhet. 2007. Distribution of the volatile compounds in the different parts of a white-flesh peach (Prunus persica L. Batsch). Food Chem. 102:375-384.

Baldwin, E.A. 2002. Fruit flavor, volatile metabolism and consumer perceptions, p. 89-106. In: M. Knee (ed.). Fruit quality and its biological basis. Sheffield Academic Press, Sheffield, UK.

Bradford, M.M. 1976. A rapid and sensitive method for the quantitation of microgram quantities of protein utilizing the principle of protein-dye binding. Anal. Biochem. 72:248-254.

Chen, G.P., R. Hackett, D. Walker, A. Taylor, Z.F. Lin, and D. Grierson. 2004. Identification of a specific isoform of tomato lipoxygenase (TomloxC) involved in the generation of fatty acidderived flavor compounds. Plant Physiol. 136:2641-2651.

Defilippi, B.G., A.M. Dandekar, and A.A. Kader. 2005. Relationship of ethylene biosynthesis to volatile production, related enzymes, and precursor availability in apple peel and flesh tissues. J. Agr. Food Chem. 53:3133-3141.

Flores, F., F.E. Yahyaoui, G. Billerbeck, F. Romojaro, A. Latché, M. Bouzayen, J.C. Pech, and C. Ambid. 2002. Role of ethylene in the biosynthesis pathway of aliphatic ester aroma volatiles in charentais cantaloupe melons. J. Expt. Bot. 53:201-206.

Friel, E.N., M. Wang, A.J. Taylor, and E.A. MacRae. 2007. In vitro and in vivo release of aroma compounds from yellow-fleshed kiwifruit. J. Agr. Food Chem. 55:6664-6673.

Gilbert, J.M., H. Young, R.D. Ball, and S.H. Murray. 1996. Volatile flavor compounds affecting consumer acceptability of kiwifruit. J. Sens. Stud. 11:247-259.

Griffiths, A., S. Prestage, R. Linforth, J. Zhang, A. Taylor, and D. Grierson. 1999. Fruit-specific lipoxygenase suppression in antisensetransgenic tomatoes. Postharvest Biol. Technol. 17:163-173.
Hatanaka, A. 1993. The biogeneration of green odour by green leaves. Phytochemistry 34:1201-1218.

Hatanaka, A., T. Kajiwara, K. Matsui, and A. Kitamura. 1992. Expression of lipoxygenase and hydroperoxide lyase activities in tomato fruits. Zeitschrift für Naturforschung Section C 47:369374.

Karakurt, Y. and D.J. Huber. 2004. Ethylene-induced gene expression, enzyme activities, and water soaking in immature and ripe watermelon (Citrullus lanatus) fruit. J. Plant Physiol. 161:381-388.

Lalel, H.J.D., Z. Singh, and S.C. Tan. 2003. Glycosidically-bound aroma volatile compounds in the skin and pulp of 'Kensington Pride' mango fruit at different stages of maturity. Postharvest Biol. Technol. 29:205-218.

Lara, I., J. Graell, M.L. López, and G. Echeverria. 2006. Multivariate analysis of modifications in biosynthesis of volatile compounds after CA storage of 'Fuji' apples. Postharvest Biol. Technol. 39:19-28.

Lara, I., R.M. Miró, T. Fuentes, G. Sayez, J. Graell, and M.L. López. 2003. Biosynthesis of volatile aroma compounds in pear fruit stored under long-term controlled-atmosphere conditions. Postharvest Biol. Technol. 29:29-39.

León, J., J. Royo, G. Vancanneyt, C. Sanz, H. Silkwski, G. Griffiths, and J. Sánchez-Serrano. 2002. Lipoxygenase H1 gene silencing reveals a specific role in supplying fatty acid hydroperoxides for aliphatic aldehyde production. J. Biol. Chem. 277:416-423.

Leone, A., T. Bleve-Zacheo, C. Gerardi, M.T. Melillo, L. Leo, and G. Zacheo. 2006. Lipoxygenase involvement in ripening strawberry. J. Agr. Food Chem. 54:6835-6844.

Li, D.P., Y.F. Xu, L.P. Sun, L.X. Liu, X.L. Hu, D.Q. Li, and H.R. Shu. 2006. Salicylic acid, ethephon, and methyl jasmonate enhance ester regeneration in 1-MCP-treated apple fruit after long-term cold storage. J. Agr. Food Chem. 54:3887-3895.

Matich, A.J., H. Young, J.M. Allena, M.Y. Wang, S. Fieldera, M.A. McNeilage, and E.A. MacRae. 2003. Actinidia arguta: Volatile compounds in fruit and flowers. Phytochemistry 63:285-301.

Porta, H. and M. Rocha-Sosa. 2002. Plant lipoxygenases. Physiological and molecular features. Plant Physiol. 130:15-21.

Ridolfi, M., S. Terenziani, M. Patumi, and G. Fontanazza. 2002. Characterization of the lipoxygenase in some olive cultivars and determination of their role in volatile compounds formation. J. Agr. Food Chem. 50:835-839.

Rogiers, S.Y., G.N.M. Kumar, and N.R. Knowles. 1998. Maturation and ripening of fruit of Amelanchier alnifolia Nutt. are accompanied by increasing oxidative stress. Ann. Bot. (Lond.) 81:203-211.

Schaffer, R.J., E.N. Friel, E.J.F. Souleyre, K. Bolitho, K. Thodey, S. Ledger, J.H. Bowen, J.H. Ma, B. Nain, D. Cohen, A.P. Gleave, R.N. Crowhurst, B.J. Janssen, J.L. Yao, and R.D. Newcomb. 2007. A genomics approach reveals that aroma production in apple is controlled by ethylene predominantly at the final step in each biosynthetic pathway. Plant Physiol. 144:1899-1912.

Wan, X.M., R.J. Stevenson, X.D. Chen, and L.D. Melton. 1999. Application of headspace solid-phase microextraction to volatile flavor profile development during storage and ripening of kiwifruit. Food Res. Int. 32:175-183.

Young, H. and V.J. Paterson. 1985. The effect of harvest maturity, ripeness and storage on kiwifruit aroma. J. Sci. Food Agr. 36:352358.

Zhang, B., K.S. Chen, J. Bowen, A. Allen, R. Espley, S. Karunairetnam, and I.B. Ferguson. 2006. Differential expression within the LOX gene family in ripening kiwifruit. J. Expt. Bot. 57:3825-3836.

Zhang, B., X.R. Yin, X. Li, S.L. Yang, I.B. Ferguson, and K.S. Chen. 2009. Lipoxygenase gene expression in ripening kiwifruit in relation to ethylene and aroma production. J. Agr. Food Chem. 57:2875-2881. 